\title{
STRATEGI PENGEMBANGAN BUMDES DALAM OPTIMALISASI POTENSI EKONOMI DESA DENGAN PENDEKATAN SOCIAL ENTREPRENEUR DI KABUPATEN KEBUMEN
}

\author{
Akhmad Syarifudin, Susi Astuti \\ Program Studi Akuntansi - STIE Putra Bangsa \\ Email: akhmadsyarifudin89@gmail.com
}

\begin{abstract}
Abstrak
Desa merupakan bagian negara sebagai unit terkecil yang terdekat dengan masyarakat yang akan disejahterakan. Pengembangan potensi ekonomi desa melalui Badan Usaha Milik Desa (BUMDes) diharapkan mengurangi ketergantungan bantuan pemerintah dan dapat mewujudkan desa yang mandiri. Potensi ekonomi desa mencapai titik optimal jika menggunakan strategi pengembangan yang tepat yang akan dibahas dalam penelitian ini. Penelitian ini termasuk jenis deskriptif kualitatif yang dilakukan di Kabupaten Kebumen, Jawa Tengah. Metode analisis SWOT (Strength, Weakness, Opportunity, Threat), digunakan untuk menentukan perencanaan strategi pengembangan BUMDes dalam meningkatkan optimalisasi pemanfaatan potensi ekonomi desa, sedangkan metode ANP (Analytical Network Process) untuk memilih prioritas alternatif strategi BUMDes dalam mengoptimalisasi potensi ekonomi desa guna meningkatkan penghasilan masyarakat dan Pendapatan Asli Desa (PADes). Populasi dalam penelitian ini mencakup seluruh desa di Kebumen yang secara administratif memiliki 449 desa dan 11 kelurahan. Pengambilan sampel sumber data dilakukan dengan cara Snowball Sampling. Teknik pengumpulan dilakukan dengan kuesioner dan wawancara. Analisis data bersifat induktif/ kualitatif, dan hasil penelitianya lebih menekan pada generalisasi. Dalam hal ini, peneliti akan memberikan gambaran sistematis dan faktual sesuai fokus penelitian.

Menurut informasi data diketahui seluruh desa di kebumen sejak tahun 2017 hingga 2019 telah mendirikan BUMDes, namun belum semua Bumdes dapat langsung membuka usaha oleh karena adanya keterbatasan baik masalah sumber daya manusia, kelembagaan, maupun permodalan. Hasil penelitian berdasarkan pembobotan dan penentuan rating dengan metode SWOT diketahui Bumdes berada di posisi Sel V, dimana pada posisi ini pengembangan BUMDes dapat dilakukan dengan strategi mempertahankan dan memelihara (hold and maintenance). Hal ini menunjukan bahwa Bumdes di Kebumen selain memiliki kekuatan dan peluang yang prospektif juga terdapat banyak kelemahan dalam menghadapi tantangan dan persaingan. Dari berbagai perencanaan strategi pengembangan Bumdes setelah dianalisis melalui metode ANP didapatkan hasil penelitian bahwa prioritas utama dalam strategi pengembangan adalah pentingnya fasilitasi modal dan perbaikan kinerja subsektor pertanian, melakukan pemetaan potensi ekonomi desa, merancang inovasi dan pengembangan produk. Alternatif prioritas strategi berikutnya yaitu meningaktkan produksi dan penetrasi pasar, memilih usaha yang profitable dan rendah resiko, mendorong peningkatan kinerja BUMDes, serta upaya optimalisasi potensi ekonomi desa dan pemanfaatan teknologi.

Berdasarkan hasil penelian diatas dapat direkomendasikan bahwa pengembangan BUMDes sangat perlu dukungan dari pemerintah melalui kebijakan regulasi, fasilitasi permodalan dan pendampingan. Selain itu, dengan melakukan perencanaan strategi pengembangan bumdes yang baik, pengamatan mendalam dan pemetaan potensi ekonomi desa, memilih usaha profitable, mengikis praktik kapitalis dan meluaskan jaringan mitra bisnis. Mengoptimalkan peran mitra ekonomi, investor dan masyarakat untuk bersama-sama dalam mendorong peningkatan produk, diversifikasi produk dan menguatkan pasar.
\end{abstract}

Kata Kunci: Strategi, Bumdes, Potensi Ekonomi Desa, Social Entrepreneur 
Research Fair Unisri 2019
Vol 4, Number 1, Januari 2020

\section{P- ISSN: 2550-0171 \\ E- ISSN: 2580-5819}

\begin{abstract}
The village is part of the state as the smallest unit closest to the community to be prospered. The existence of villages in institutional structures has been strengthened by the provisions of Law No. 6 of 2014 concerning Villages. The development of the economic potential of the village through the Village Owned Enterprises (BUMDes) is expected to reduce dependence on government assistance and can create an independent village. The economic potential of the village reaches an optimal point if it uses the right development strategy that will be discussed in this study. This research is a qualitative descriptive study conducted in Kebumen Regency, Central Java. The SWOT (Strength, Weakness, Opportunity, Threat) analysis method is used to determine the BUMDes development strategy planning to improve the optimization of the economic potential utilization of the village, while the ANP (Analytical Network Process) method to select alternative priorities of the BUMDes strategy in optimizing the economic potential of the village in order to increase income community and Village Original Income (PADes). The population in this study includes all villages in Kebumen which administratively has 449 villages and 11 villages. Data source sampling is done by Snowball Sampling. The collection technique is done by questionnaire and interview. Data analysis is inductive / qualitative, and the results of research are more pressing on generalization. In this case, the researcher will provide a systematic and factual description according to the focus of the study.

According to data information, it is known that all villages in Kebumen from 2017 to 2019 have established BUMDes, but not all Bumdes can immediately open a business due to limitations both in terms of human, institutional and capital problems. The results of research based on weighting and determination of the rating using the SWOT method are known Bumdes is in the position of Cell V, where in this position the development of BUMDes can be done with a strategy of maintaining and maintaining (hold and maintenance). This shows that Bumdes in Kebumen besides having prospective strengths and opportunities there are also many weaknesses in facing challenges and competition. From various Bumdes development strategy planning after being analyzed through the ANP method it was found that the main priority in the development strategy was the importance of capital facilitation and improvement of the performance of the agricultural subsector, mapping the economic potential of the village, designing innovations and developing products. The next alternative priority strategy is to increase production and market penetration, choose businesses that are profitable and low risk, encourage the improvement of BUMDes performance, as well as efforts to optimize the economic potential of the village and the use of technology.

Based on the results of the study above it can be recommended that the development of BUMDes really needs support from the government through regulatory policies, capital facilitation and assistance. In addition, by planning good development strategies for village planning, in-depth observation and mapping of the economic potential of villages, choosing profitable businesses, eroding capitalist practices and expanding the network of business partners. Optimizing the role of economic partners, investors and the public to work together in encouraging product improvement, product diversification and strengthening the market.
\end{abstract}

Keywords :_Strategy, Bumdes, Village Economic Potential, Social Entrepreneur 
Research Fair Unisri 2019

Vol 4, Number 1, Januari 2020
P- ISSN: 2550-0171

E- ISSN: 2580-5819

\section{PENDAHULUAN}

Paradigma baru untuk membangun Indonesia dari pinggiran dengan memperkuat daerah-daerah dan desa dalam kerangka NKRI, merupakan salah satu program Nawacita Presiden RI. Desa merupakan bagian unit terkecil dari negara yang sangat dekat dengan masyarakat dan secara riil langsung menyentuh kebutuhan akan kesejahteraan masyarakat. Eksistensi desa dalam struktur kelembagaan dan pembangunan semakin diperkuat dengan ditetapkannya Undang-Undang Nomor 6 tahun 2014 tentang Desa. Sebelum terbitnya UU ini, desa masih dipandang sebagai obyek pembangunan semata, sehingga program pembangunan dari pemerintah melalui dinas terkait kadang tidak sesuai dengan kebutuhan desa.

Terbitnya UU No.6/2014 menjadikan desa sebagai subyek pembangunan yang merupakan era baru dalam manajemen tata pemerintahan dan pengelolaan keuangan desa. Pemerintah dan DPR melalui UU Desa menempatkan desa sebagai satu kesatuan masyarakat hukum dan satu kesatuan entitas sosial-politik-budaya yang mandiri. Undangundang ini memposisikan Desa menjadi daerah otonom bedasarkan adat istiadat dan kearifan lokal sebagai basis SDM dan sumber daya alam. Untuk itu perlu peningkatan kapasitas desa agar lebih berdaya sebagai subyek pembangunan.

Sesuai UU No. 6 Tahun 2014, pembangunan masyarakat desa adalah upaya yang dilakukan secara terencana dan berkelanjutan untuk mencapai masyarakat desa yang dicita-citakan guna mencapai masyarakat sejahtera (perubahan pola hidup dan tingkah laku dari masyarakat yang tradisional menjadi berfikir modern). Untuk mendukung kewenangan desa yang lebih luas, mulai tahun 2015 desa juga diberi anggaran yang besar dari APBN untuk membiayai pembangunan wilayahnya sesuai dengan potensi dan kebutuhan desa.

Pembangunan merupakan proses yang berkelanjutan dengan tujuan untuk mencapai kesejahteraan masyarakat. Atas tujuan tersebut, strategi pembangunan harus diletakankan pada bidang pembangunan produksi dan infrastruktur untuk memacu pertumbuhan ekonomi serta peningkatan kualitas sumber daya manusia
(SDM). Pada bidang perekonomian, pembangunan harus lebih ditekankan pada peningkatan pertumbuhan ekonomi dan pendapatan per kapita yang akan menguatkan daya beli masyarakat. Pengembangan basis ekonomi di perdesaan sudah sejak lama dijalankan oleh Pemerintah melalui berbagai program misalnya Program Penanggulangan Kemiskinan Perkotaan ( P2KP), Program UPK-PKP-PKK dan program lainya namun upaya itu belum memuaskan sebab kemiskinan di pedesaan masih tergolong tinggi.

Strategi Pengembangan potensi ekonomi desa melalui BUMDes merupakan alternatif solusi yang diamantkan UU untuk mengurangi ketergantungan bantuan pemerintah dan mampu menjadi desa mandiri. BUMDes merupakan badan usaha yang didirikan pemerintahan desa yang dikelola oleh masyarakat. Pembentukan BUMDes dilakukan berdasarkan kesepakatan masyarakat dan pemerintah desa melalui musyawarah dengan tujuan untuk menggerakan perekonomian di desa dan meningkatkan Penghasilan Asli Desa (PADes). Munculnya BUMDes diproyeksi-kan dapat mejadi kekuatan ekonomi baru di desa. Sesuai peraturan Permendes dan PDTT No. 4 Tahun 2015 (Pasal 19) terdapat enam bentuk usaha BUMDes diantaranya yaitu; usaha sosial, persewaan, brokering, membuka unit usaha perdesaan, dan usaha sub sektor pertanian. Selain itu BUMdes juga bisa membuka usaha jasa perbankan, jasa konstruksi, usaha perdagangan, kerajinan, dan lain-lain.

Penelitian ini akan dilakukan di Kabupaten Kebumen Jawa Tengah yang memiliki 26 Kecamatan dan 449 desa. Jumlah penduduknya 1.188.622 jiwa terdiri laki-laki 591.891 dan perempuan 596731 jiwa. Secara geografis lokasi desa-desa di Kab. Kebumen berada di wilayah pegunungan, dataran rendah, dan kawasan pesisir pantai selatan Jawa. Masing-masing wilayah pedesaan tersebut memiliki karakteristik dan keunggulan. Sepanjang daerah KarangsambungKarangbolong merupakan kawasan geopark Nasional yang menyimpan berbagai potensi kekayaan alam. Pada kawasan dataran rendah tanahnya sangat subur dan padat penduduk, 
Research Fair Unisri 2019

Vol 4, Number 1, Januari 2020
P- ISSN: 2550-0171

E- ISSN: 2580-5819 sedangkan dikawasan pesisir memiliki banyak potensi baik sektor pertanian, industri maupun wisata. Namun kondisi ekonomi masyarakat masih banyak kelompok marginal, bahkan merupakan daerah termiskin ke-2 di Jateng. Pembentukan Bumdes oleh pemerintah diharapkan dapat meningkatkan ekonomi masyarakat pedesaan.

Sesuai Intruksi Kepala Daerah, pada tahun 2016 hampir semua desa sudah membentuk BUMDes, namun dari data yang penulis dapatkan 179 yang berjalan dan 56 yang sudah aktif menjalankan usaha. Berdasarkan latar belakang yang telah diuraikan, rumuskan masalah dalam penelitian yaitu; Bagaimana alternatif strategi Pengembangan BUMDes dalam mengoptimalisasi potensi ekonomi desa.. Tujuan penelitian adalah untuk mengetahui alternatif strategi Pengembangan BUMDes yang cocok dengan menggunakan analisis SWOT dan untuk mengetahui prioritas strategi dalam mengoptimalisasi potensi ekonomi desa di Kabupaten Kebumen dengan menggunakan metode Analytical Network Process (ANP).

\section{KAJIAN PUSTAKA}

\section{Badan Usaha Milik Desa}

Pengertian Badan Usaha Milik Desa atau disingkat BUMDes menurut Undang - Undang No. 6 Tahun 2014 adalah badan usaha yang seluruh atau sebagian besar modalnya dimiliki oleh desa melalui penyertaan secara langsung yang berasal dari kekayaan desa yang dipisahkan guna mengelola aset, jasa pelayanan, dan usaha lainnya untuk sebesarbesarnya kesejahteraan masyarakat desa.

Badan Usaha Milik Desa (BUMDes) merupakan perwujudan dari pengelolaan ekonomi produktif desa yang dilakukan secara kooperatif, partisipatif, emansipatif, transparansi, akuntabel, dan sustainable (Pusat Kajian Dinamika Sistem Pembangunan, 2007).

\section{Jenis - Jenis Usaha BUMDes}

1. Usaha sosial. Yaitu BUMDes menjalankan pelayanan public kepada masyarakat dengan memperoleh keuntungan finansial.

2. Jenis usaha persewaan. BUMDes menjalankan usaha penyewaan barang untuk melayani kebutuhan masyarakat desa dan ditujukan untuk memperoleh pendapatan.

3. Jenis usaha BUMDes yang ketiga adalah usaha perantara / brokering. Yaitu BUMDes dapat menjalankan usaha perantara (brokering) yang memberikan jasa pelayanan masyarakat.

4. Membuka unit usaha yang dikembangkan masyarakat Desa baik dalam skala lokal Desa maupun kawasan perdesaan.

5. Jenis usaha keuangan. Yaitu usaha keuangan (financial business) yang memenuhi kebutuhan usaha-usaha skala mikro yang dijalankan oleh pelaku usaha ekonomi desa

6. Jenis usaha bersama/ holding. BUMDes dapat menjalankan usaha bersama (holding) sebagai induk dari unit usaha, kebutuhan masyarakat, sumber daya manusia, sarana prasarana, modal dan daya beli masyarakat.

\section{Potensi Ekonomi Desa}

Indonesia sebagai negara kepulauan dikenal sebagai negara yang memiliki kakayaan alam yang melimpah. Tingginya Potensi kekayaan alam di daerah/ desa, masih sangat banyak yang belum digarap secara optimal. Kondisi tersebut merupakan salah satu kelemahan kita sehingga menyebkan kesejahteraan bagi masyarakat desa belum berlaku secara menyeluruh. "Desa-desa di Indonesia memiliki lahan pertanian yang luas dan sangat subur. Kondisi wilayah desa sangat memungkinkan untuk mengembakan berbagai macam potensi ekonomi baik subsektor pertanian, agroindustri agrobisnis maupun misalnya membuka kebun an pengolahan aneka buah-buahan, aneka bunga. Membuka usaha kerajinan UMKM, sektor pertanian, keindahan alam, selain itu juga masih banyak lagi potensi lain yang bisa dieksplorasi untuk kemajuan ekonomi desa dan kawasan perdesaan demi kesejahteraan masyarakat.

\section{POTENSI EKONOMI DESA DI KEBUMEN}

\begin{tabular}{llllllllll}
\hline \begin{tabular}{l} 
KECAMAT \\
\multicolumn{1}{c}{ AN }
\end{tabular} & Pr & Pt & $\mathbf{P k}$ & $\mathbf{K h}$ & $\mathbf{P b}$ & $\mathbf{K r}$ & $\mathbf{K l}$ & $\begin{array}{c}\mathbf{O} \\
\mathbf{w}\end{array}$ \\
\hline Ayah & $\sqrt{ }$ & $\sqrt{ }$ & $\sqrt{ }$ & $\sqrt{ }$ & $\sqrt{ }$ & - & - & $\sqrt{ }$ \\
Buayan & $\sqrt{ }$ & $\sqrt{ }$ & $\sqrt{ }$ & $\sqrt{ }$ & $\sqrt{ }$ & - & - & - \\
Puring & $\sqrt{ }$ & $\sqrt{ }$ & $\sqrt{ }$ & $\sqrt{ }$ & $\sqrt{ }$ & - & - & $\sqrt{ }$
\end{tabular}


Research Fair Unisri 2019

Vol 4, Number 1, Januari 2020
P- ISSN: 2550-0171

E- ISSN: 2580-5819

\begin{tabular}{lllllllll} 
Petanahan & $\sqrt{ }$ & $\sqrt{ }$ & $\sqrt{ }$ & $\sqrt{ }$ & - & $\sqrt{ }$ & - & $\sqrt{ }$ \\
Klirong & $\sqrt{ }$ & $\sqrt{ }$ & $\sqrt{ }$ & $\sqrt{ }$ & - & $\sqrt{ }$ & - & $\sqrt{ }$ \\
Bulus Pesantren & $\sqrt{ }$ & $\sqrt{ }$ & $\sqrt{ }$ & $\sqrt{ }$ & - & - & - & $\sqrt{ }$ \\
Ambal & $\sqrt{ }$ & $\sqrt{ }$ & $\sqrt{ }$ & $\sqrt{ }$ & - & - & $\sqrt{ }$ & - \\
Mirit & $\sqrt{ }$ & $\sqrt{ }$ & $\sqrt{ }$ & $\sqrt{ }$ & - & - & - & $\sqrt{ }$ \\
Bonorowo & $\sqrt{ }$ & $\sqrt{ }$ & $\sqrt{ }$ & $\sqrt{ }$ & - & - & - & - \\
Prembun & $\sqrt{ }$ & $\sqrt{ }$ & $\sqrt{ }$ & $\sqrt{ }$ & - & - & - & $\sqrt{ }$ \\
Padureso & $\sqrt{ }$ & $\sqrt{ }$ & $\sqrt{ }$ & $\sqrt{ }$ & $\sqrt{ }$ & - & - & - \\
Kutowinangun & $\sqrt{ }$ & $\sqrt{ }$ & $\sqrt{ }$ & $\sqrt{ }$ & $\sqrt{ }$ & - & - & $\sqrt{ }$ \\
Alian & $\sqrt{ }$ & $\sqrt{ }$ & $\sqrt{ }$ & $\sqrt{ }$ & $\sqrt{ }$ & $\sqrt{ }$ & - & $\sqrt{ }$ \\
Poncowarno & $\sqrt{ }$ & $\sqrt{ }$ & $\sqrt{ }$ & $\sqrt{ }$ & - & - & - & $\sqrt{ }$ \\
Kebumen & $\sqrt{ }$ & $\sqrt{ }$ & $\sqrt{ }$ & $\sqrt{ }$ & $\sqrt{ }$ & $\sqrt{ }$ & $\sqrt{ }$ & $\sqrt{ }$ \\
Pejagoan & $\sqrt{ }$ & $\sqrt{ }$ & $\sqrt{ }$ & $\sqrt{ }$ & $\sqrt{ }$ & $\sqrt{ }$ & - & $\sqrt{ }$ \\
Sruweng & $\sqrt{ }$ & $\sqrt{ }$ & $\sqrt{ }$ & $\sqrt{ }$ & $\sqrt{ }$ & - & - & $\sqrt{ }$ \\
Adimulyo & $\sqrt{ }$ & $\sqrt{ }$ & $\sqrt{ }$ & $\sqrt{ }$ & $\sqrt{ }$ & - & $\sqrt{ }$ & $\sqrt{ }$ \\
Kuwarasan & $\sqrt{ }$ & $\sqrt{ }$ & $\sqrt{ }$ & $\sqrt{ }$ & - & - & $\sqrt{ }$ & - \\
Rowokele & $\sqrt{ }$ & $\sqrt{ }$ & $\sqrt{ }$ & $\sqrt{ }$ & $\sqrt{ }$ & - & - & $\sqrt{ }$ \\
Sempor & $\sqrt{ }$ & $\sqrt{ }$ & $\sqrt{ }$ & $\sqrt{ }$ & $\sqrt{ }$ & $\sqrt{ }$ & - & $\sqrt{ }$ \\
Gombong & $\sqrt{ }$ & $\sqrt{ }$ & $\sqrt{ }$ & $\sqrt{ }$ & $\sqrt{ }$ & $\sqrt{ }$ & - & $\sqrt{ }$ \\
Karanganyar & $\sqrt{ }$ & $\sqrt{ }$ & $\sqrt{ }$ & $\sqrt{ }$ & $\sqrt{ }$ & $\sqrt{ }$ & - & $\sqrt{ }$ \\
Karanggayam & $\sqrt{ }$ & $\sqrt{ }$ & $\sqrt{ }$ & $\sqrt{ }$ & $\sqrt{ }$ & $\sqrt{ }$ & - & $\sqrt{ }$ \\
Sadang & - & $\sqrt{ }$ & $\sqrt{ }$ & $\sqrt{ }$ & $\sqrt{ }$ & - & - & $\sqrt{ }$ \\
Karangsambung & - & $\sqrt{ }$ & $\sqrt{ }$ & $\sqrt{ }$ & $\sqrt{ }$ & - & - & $\sqrt{ }$ \\
\hline Sumer Kebum & $d$ & &
\end{tabular}

Sumber: Kebumen dalam angka, data diolah (2019)

Keterangan:

Pr : Perikanan (Tawas, Karper, Nila, Mujahir, Lele, Gabus, Udang darat, Sepat siem, Sidat, Belut)

Pt : Peternakan (Sapi potong, Kerbau, Kambing, Domba, Kelinci, Kuda)

$\mathrm{Pk}$ : Perkebunan (Kelapa)

$\mathrm{Kh}$ : Kehutanan (Jati, Mahoni, Albasia, Akasia, Rimbalain)

$\mathrm{Pb}$ : Pertambangan (Diabas, Gabro, Basal, Breksi, Marmer)

$\mathrm{Kr}$ : Kerajinan (Gerabah, Guji Bergambar,Tudung,Batik Tulis,Anyaman Bambu)

Kl : Kuliner (Sate Ambal, Nasi Penggel, Jipang Kacang, Lanting)

Ow :Objek Wisata (Menganti, Logending, Lampon, Karang Agung, Sawangan, Gunung Duwur, Hutan Mangrove, Gua jati jajar, Gua Petruk, Gua Barat, Pecaron,Air Terjun Superman Big sister,Pantai Gebyuran, Bukit Sianco, Karang Bata, Jembatan Merah, Tanjung Karang Penganten, Surumanis)

Kewirausahaan Sosial (social entrepreneur)

Salah satu program pengentasan kemiskinan

di pedesaan adalah Kewirausahaan Sosial. Kewirausahaan sosial bukan hanya menciptakan peluang peningkatan pendapatan, tetapi juga sekaligus menyelesaikan berbagai persoalan sosial.

Fokus bisnis dalam kewirausahaan sosial tidak hanya berorientasi pada keuntungan laba, tetapi juga berorientasi pada kesejahteraan masyarakat sekitar. Kemampuan kewirausahaan sosial membuka partisipasi pada banyak orang dengan sendirinya memecahkan berbagai persoalan sosial seperti pengangguran, kekurangan gizi dan sebagainya.

\section{Penelitian Terdahulu}

Penelitian Jaka Sulaksana dan Irni Mulyanti (2019) di Desa Cibunut Kec. Argapura Kab. Majalengka menghasilkan 11 strategi pengembangan yang menjadi prioritas utama untuk pengembangan BUMDes Mitra Sejahtera dengan nilai TAS (Total Atractif Score) tertinggi sebesar menghasilkan 0,76. Penelitian Strategi Pengembangan Badan Usaha Milik Desa (BumDes) oleh Dodi Yudiadi (2015) di kabupaten Garut menghasilkan prioritas strategi pengembangan BUMDes yaitu dengan pembentukan ikatan kerjasama dengan lembaga pengembangan lain, kemudian dilanjutkan dengan diversifikasi produk, penetrasi pasar, pengembanagan produk BUMDes, pelatihan karyawan.

\section{METODE PENELITIAN}

Penelitian ini merupakan jenis penelitian deskriptif dengan pendekatan kualitatif. Populasi dalam penelitian ini yaitu seluruh BUMDes di Kabupaten Kebumen yang terdapat 449 Desa. Pengambilan sampel sumber data dilakukan dengan cara Snowball Sampling. Sampel yang digunakan yaitu BUMDes yang sudah menjalankan aktifitas usaha.

\section{Teknik Pengumpulan Data}

Pengumpulan data primer diperoleh dengan cara menyebarkan kuisioner dan wawancara langsung dengan pemerintah desa, pengurus bumdes dan tokoh masyarakat yang memenuhi kriteria. Selain itu peneliti juga melakuan wawancara dengan pihak terkait dan melakukan diskusi (FGD) dengan para pengurus Bumdes. Penyebaran kuisioner ke responden dilakukan setelah mendapat surat ijin resmi dari Dinas Kesbangpol dan Bapeda Kabupaten Kebumen.

\section{Metode Analisis Data}

Penelitian ini menggunakan dua metode yang saling berkaitan. Metode analisis SWOT (Strength, Weakness, Opportunity, Threat) digunakan untuk menentukan strategi Pengembangan BUMDes dalam optimalisasi 


\section{Research Fair Unisri 2019 \\ Vol 4, Number 1, Januari 2020}

\section{P- ISSN: 2550-0171 \\ E- ISSN: 2580-5819}

potensi ekonomi desa. Analisis SWOT merupakan alat analisis yang digunakan untuk mengidentifikasi berbagai faktor yang berpengaruh dalam merumuskan strategi perusahaan (Lipinski, 2002; Rangkuti, 2006).

Penggunaan metode ANP (Analytical Network Process) untuk memilih alternatif strategi BUMDes dalam optimalisasi potensi ekonomi desa untuk meningkatkan penghasilan masyarakat dan Pendapatan Asli Desa (PADes). Metode ANP merupakan sebuah cara yang digunakan untuk menyelesaikan permasalahan Multi Criteria Decision Making (Saaty, 2006; Singgih 2009). Metode ini dapat untuk merepresentasikan tingkat kepentingan berbagai alternatif solusi berdasarkan pertimbangan keterkaitan antar kriteria dan sub kriteria yang ada (Saaty, 2006; Sapto, 2008; Suswono, 2010).

\section{HASIL DAN PEMBAHASAN}

Kondisi perekonomian Kebumen dipandang dari pertumbuhan ekonominya tertingi di eks Karesidenan Kedu mencapai 6,29\%, bahkan lebih tinggi dari pertumbuhan ekonomi di Jawa Tengah sebesar 5,4\%. Akan tetapi kemiskinan di Kebumen masih tinggi sebesar $20,44 \%$ sebagai daerah termiskin kedua di Jawa Tengah. Jumlah penduduk Kebumen sebanyak 1.155.437 jiwa dengan kepadatan 738,7 jiwa/km persegi yang mayoritas pekerjaanya adalah sebagai petani. Kepadatan jumlah penduduk ini merupakan potensi pasar terutama bagi dunia industri dan perdagangan. Penetapan Upah Minimum Kabupaten/kota (UMK) untuk tahun 2019 di daerah kota Beriman ini juga masih rendah hanya sebesar Rp 1.686.000. Hal ini merupakan potensi ekonomi yang sangat menarik bagi investor untuk hadir dan berinvestasi karena dari sektor upah memiliki tingkat efisiensi yang tinggi dibanding UMK dikota besar seperti Jakarta yang mencapai Rp.3.900.000. Tingginya pertumbuhan ekonomi tersebut dan keunikan kekayaan alam yang terdapat di Kebumen merupakan suatu keunggulan dan terbuka adanya kesempatan yang luas untuk dikembangkan dalam rangka meningkatkan perekonomian masyakat.
Potensi ekonomi dari sisi wilayah geografis, dominasi wilayah Kebumen berupa desa yang terdiri dari 449desa dan 11 keluraan, dimana terdapat lebih dari 95 potensi wisata yang tersebar di 26 kecamatan. Pada tahun 2018 untuk area sepanjang wilayah karangsambung-karangbolong Kebumen dtetapkan sebagai kawasan Geopark Nasional. Hal ini merupakan primadona destinasi pilihan karena adanya perpaduan antara wisata alam dan budaya yang dimiliki. Kontribusi destinasi wisata terhadap Pendapatan Asli Daerah (PAD) dikebumen juga cukup besar. Wilayah geografis di bagian utara dan bagian barat Kota Kebumen terdapat pegunungan dengan berbagai potensi sumber daya alam. Dibagian tengah berupa dataran rendah dimana terdapat banyak lahan pertanian yang subur, tempat industri maupun sebagai pusat pemerintahan dan perdagangan. Sedangkan dibagian pesisir pantai selatan laut jawa memiliki potensi pertanian palawija, perikanan, pembuatan garam, dan pengembangan industri serta keindahan pantai untuk wisata.

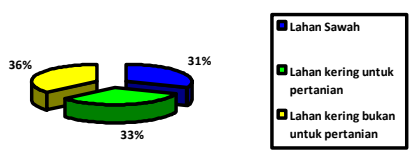

Gambar 1. Diagram Jenis dan luas penggunaan Lahan di Kabupaten Kebumen Sumber : Kebumen Dalam Angka

1. Pembagian lahan sawah menurut sistem irigasinya terbagi sebagai berikut:

a. Lahan sawah beririgasi teknis sebesar $50,34 \%$, hampir keseluruhan dapat ditanami 2 kali dalam setahun

b. Lahan sawah beririgasi setengah teknis sebesar $9,23 \%$

c. Lahan sawah irigasi sederhana5,77\%

d. Lahan sawah beririgasi desa $2,65 \%$

e. Lahan berupa sawah tadah hujan dan pasang surut sebesar $32,02 \%$.

2. Lahan kering dengan fungsi untuk pertanian terbagi sebagai berikut:
a. Tegal/kebun seluas $27.629,00$ hektar
b. Ladang/huma seluas 745,00 hektar 
Research Fair Unisri 2019

Vol 4, Number 1, Januari 2020
P- ISSN: 2550-0171

E- ISSN: 2580-5819 c. Perkebunan seluas $1.159,00$ hektar

d. Hutan rakyat seluas 3.011,00 hektar

e. Tambak seluas 24,00 hektar

f. Kolam seluas 53,50 hektar

g. Padang penggembalaan 33,00 hektar

h. Tidak diusahakan 231,00 hektar

i. Lainnya seluas $9.914,00$ hektar.

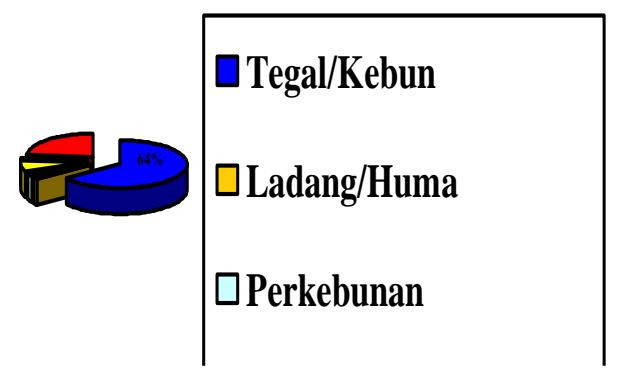

Gambar 2. Diagram Jenis dan luas penggunaan

Lahan kering untuk pertanian

Sumber : Kebumen Dalam Angka

Sedangkan lahan kering yang bukan untuk pertanian digunakan untuk bangunan seluas 26.021,00 hektar, hutan negara seluas 16.861,00 hektar, rawa-rawa seluas 12,00 hektar serta lainnya seluas 2.670 hektar. Di lahan kering tersebut didalamnya terdapat potensi untuk tanaman komersi, bahan galian, sebagai obyek wisata dan pemanfaan lainya.

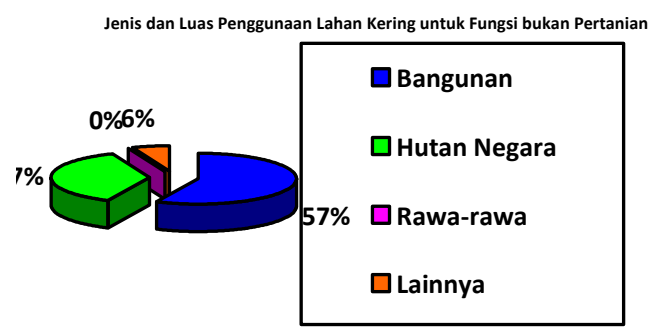

Gambar 3. Diagram Jenis dan luas penggunaan

Lahan kering bukan pertanian

Sumber : Kebumen Dalam Angka

Dari diagram nampak masih terdapat lahan yang belum dimanfaatkan dengan baik agar lebih produktif seperti rawa-rawa dan lahan lainya yang luasnya mencapai 9.914,00ha. Lahan tersebut seperti lahan tandus dan lahan pekarangan yang kebanyakan hanya ditumbuhi jenis pepohonan alas/ tanaman liar. Berbagai macam potensi yang menjadi keunggulan Kebumen antara lain: sawah, pekarangan, peternakan, perkebunan, pasar, sumberdaya alam agrobisnis, agroindustry, wisata, sumberdaya laut, jasa keuangan. Salah satu potensi daerah yang menjadi unggulan dan sangat potensial untuk dikembangkan adalah bidang sektor pariwisata. misalnya wisata pantai Menganti yang telah dikembangkan oleh bumdes desa Karangduwur Kecamatan Ayah. Kemudian obyek wisata Brujul adventure yang dikembangkan oleh Bumdes Desa Peniron Kecamatan Pejagoan.

\section{Pembentukan BUMDes di Kebumen}

Amanat pembentukan BUMDes didasarkan pada UU No.6 Tahun 2014 tentang Desa dengan maksud untuk menggali sumber kekayaan alam dan potensi ekonomi desa serta pemanfaatanya untuk meningkatkan ekonomi lokal. Berlakunya regulasi tentang Desa, kini desa memasuki era self governing community dimana Desa memiliki otonomi dan kewenangan dalam perencanaan, pelayanan publik, dan keuangan.

Prinsip dalam pembentukan BUMDes adalah untuk meningkatkan ekonomi masyarakat dan peningkatan Pendapatan Asli Desa (PADes). Pada PP Nomor 43 Tahun 2014 yang diubah melalui PP No. 47 Tahun 2015 disebutkan bahwa kini desa mempunyai wewenang untuk mengatur sumber daya dan arah pembangunan. Beberapa desa di Kebumen sejak tahun 2016 mulai membentuk Bumdes dan makin pesat sejak terbitnya Peraturan Daerah Nomor 6 Tahun 2017 yang mengatur tentang Pedoman Pendirian, Pengurusan, dan Pengelolaan Bumdes. Hingga tahun 2019 seluruh desa di Kebumen telah terbentuk Bumdes yang dalam proses pendirianya didampingi oleh pendamping desa. Secara nasional jumlah Bumdes yang terbentuk pada bulan Juli 2018 mencapai 35 ribu dari 74.910 desa.

Berikut sebagian daftar nama Bumdes di Kebumen :

\begin{tabular}{|l|l|}
\multicolumn{2}{c}{ Tabel 1 Daftar BUMDes } \\
\hline KECAMATAN & \multicolumn{1}{c|}{ DESA } \\
\hline \multirow{3}{*}{ Ayah } & $\begin{array}{l}\text { Jatijajar, kedungwaru, Srati, Argosari, } \\
\text { Karangnduwur, Kalipoh, Pasir, Tlogosari, } \\
\text { Watu Kelir, Ayah, Banjararjo, Argopeni, } \\
\text { Jintung, Bulurejo, Kalibangkang }\end{array}$ \\
\hline Buayan & $\begin{array}{l}\text { Geblug, Wonodadi, karangbolong, } \\
\text { Karangsari, Banyumudal }\end{array}$ \\
\hline Puring & $\begin{array}{l}\text { Sitiadi, Kradegan, Srusuh Juru Tengah, } \\
\text { Purwosari, Pasuruhan, Arjowinangun, }\end{array}$ \\
\hline
\end{tabular}


Research Fair Unisri 2019

Vol 4, Number 1, Januari 2020
P- ISSN: 2550-0171

E- ISSN: 2580-5819

\begin{tabular}{|c|c|}
\hline & Tambah Mulyo \\
\hline Petanahan & $\begin{array}{lrl}\text { Jogomertan, } & \text { Petanahan, } & \text { Ampelsari, } \\
\text { Grujugan, } & \text { Kewangunan, } & \text { Kebonsari, } \\
\text { Jatimulyo, Tresnorejo } & \end{array}$ \\
\hline Klirong & $\begin{array}{l}\text { Klirong,Jatimalang,Kedungwinangun,Jogo } \\
\text { simo,Gebangsari,Kedungsari, Gadungrejo, } \\
\text { Bumiharjo }\end{array}$ \\
\hline Bulus Pesantren & $\begin{array}{l}\text { Ampih, Klapasawit, Buluspesantren, } \\
\text { Setrojenar }\end{array}$ \\
\hline Ambal & $\begin{array}{l}\text { Pucangan, Dukuhrejosari, Benerwetan, } \\
\text { Ambalwinangun, Sidareja }\end{array}$ \\
\hline Mirit & $\begin{array}{l}\text { Wiromartan, Lembupurwo,Selotumpeng, } \\
\text { Wergonayan }\end{array}$ \\
\hline Bonorowo & $\begin{array}{l}\text { Bonjok Kidul,Bonjok Lor, Bonorowo, } \\
\text { Rowosari }\end{array}$ \\
\hline Prembun & Prembun, Bagung, Pesuningan, Pecarikan \\
\hline Padureso & $\begin{array}{l}\text { Balingasal, Padureso, Pejengkolan, } \\
\text { Sendang dalem, Rahayu }\end{array}$ \\
\hline Kutowinangun & Kaliputih, Pejagatan, Kuwarisan \\
\hline Alian & $\begin{array}{l}\text { Sawangan,Kemangguan, Wonokromo, } \\
\text { Jatimulyo }\end{array}$ \\
\hline Poncowarno & $\begin{array}{l}\text { Poncowarno,Lerepkebumen,Jembangan, } \\
\text { Kedungdowo, Jatipurus }\end{array}$ \\
\hline Kebumen & $\begin{array}{l}\text { Jemur,Muktisari,Adikarso,Gemeksekti,me } \\
\text { ngkowo,Karangsari, Kalijirek, Kalibagor, } \\
\text { Gesikan }\end{array}$ \\
\hline Pejagoan & $\begin{array}{l}\text { Peniron, jemur, Pengaringan, Karangpoh, } \\
\text { Pejagoan, Logede }\end{array}$ \\
\hline Sruweng & $\begin{array}{lcr}\text { Karangjambu, } & \text { Tanggeran, } & \text { Karangsari, } \\
\text { Giwangretno, } & \text { Penusupan, } & \text { Trikarso, } \\
\text { Sidoarjo, pandansari, Sidoagung } & \end{array}$ \\
\hline Adimulyo & Candiwulan, Adiluhur, Temanggal \\
\hline Kuwarasan & $\begin{array}{l}\text { Madureso, Tambaksari, } \\
\text { Wonoyoso, Kalipurwo, } \\
\text { Sidomukti, Harjodowo }\end{array}$ \\
\hline Rowokele & $\begin{array}{l}\text { Kretek, Giyanti, Kalisari, Pringtutul, } \\
\text { Wagirpandan, Sukomulyo, Wonoharjo }\end{array}$ \\
\hline Sempor & $\begin{array}{l}\text { Kedungjati, Sampang, kalibeji, Selokerto, } \\
\text { Tanjung seto }\end{array}$ \\
\hline Gombong & $\begin{array}{lll}\text { Kemukus, } & \text { kalitengah, } & \text { Klopogodo, } \\
\text { Semanding } & \end{array}$ \\
\hline Karanganyar & $\begin{array}{l}\text { Grenggeng, Pohkumbang, Wonorejo, } \\
\text { Giripurno, Sidomulyo Mandiri }\end{array}$ \\
\hline Karanggayam & $\begin{array}{l}\text { Kalirejo, Logandu, karanggayam, Kajoran, } \\
\text { Glontor, Pagebangan, Giritirto, Penimbun, } \\
\text { Selogiri, Clapar, Gunungsari }\end{array}$ \\
\hline Sadang & Seboro \\
\hline Karangsambung & $\begin{array}{l}\text { Widoro, Seling, Kedungwaru, Pujotirto, } \\
\text { Wadasmalang, } \\
\text { Kalisana,Karangsambung, Plumbon }\end{array}$ \\
\hline
\end{tabular}

Tabel 2 Perkembangan Usaha Bumdes Di Kabupeten Kebumen

\begin{tabular}{|c|c|c|c|c|c|}
\hline & $\begin{array}{l}\text { Unggulan } \\
\text { bumdes }\end{array}$ & $\begin{array}{l}\text { Berke- } \\
\text { mbang } \\
\text { Pesat }\end{array}$ & $\begin{array}{l}\text { Mulai } \\
\text { Berke } \\
\text { mbang }\end{array}$ & $\begin{array}{c}\text { Kurang } \\
\text { Berkem } \\
\text { bang }\end{array}$ & $\begin{array}{l}\text { Jumlah } \\
\text { Bumdes }\end{array}$ \\
\hline 1 & Retail & 3 & 19 & 12 & 35 \\
\hline 2 & Industri & 4 & 9 & 3 & 16 \\
\hline 3 & Perdagangan & 3 & 4 & 7 & 14 \\
\hline 4 & Jasa umum & 1 & 3 & 0 & 4 \\
\hline 5 & Pari wisata & 5 & 3 & 2 & 10 \\
\hline 6 & Pertanian & 1 & 8 & 6 & 15 \\
\hline 7 & Peternakan & 3 & 12 & 5 & 20 \\
\hline 8 & Perikanan & 1 & 5 & 4 & 10 \\
\hline 9 & Persewaan & 2 & 4 & 0 & 6 \\
\hline 10 & Simpa pinjam & 1 & 3 & 5 & 9 \\
\hline \multicolumn{2}{|c|}{ Jumlah } & 24 & 70 & 44 & 140 \\
\hline
\end{tabular}

Dari hasil wawancara ke bumdes dan informasi dari Asosiasi Bumdes kabupaten Kebumen, pada tahun 2019 dari 449 desa terdapat 179 Bumdes yang sudah mulai membuka kegiatan usaha. Kepengurusan Bumdes rata-rata terdiri dari 712 orang, selain pengawas dan pelindung/ komisaris (kepala desa) tergantung dari banyaknya bidang usaha yang dikelola. Selain memberi permodalan Pemerintah Daerah juga telah memberikan pelatihan manajemen kewirausahaan. Keberadaan Bumdes dengan melibatkan warga masyarakat yang berjiwa wirausaha, diharapkan dapat menciptakan nila tambah (value added) dan menumbuhkan Pendapatan Asli Desa. Bidang usaha yang dijalankan oleh tiap Bumdes pun beragam terdiri dari industri, perdagangan, peternakan, pertanian ,membuka tempat wisata, kerajinan serta usaha layanan jasa keuangan dan simpan pinjam. Pendirian Bumdes ditetapkan melalui peraturan desa dan oleh pemerintah desa setempat dan diberi permodalan awal yang bervariasi kisaran 20-250 juta rupaiah yang sumbernya berasal dari Dana Desa (DD). Pada awal operasi usahanya, sebanyak 56 bumdes pada tahun 2018 ikut menjadi penyalur program bantuan pangan non tunai (BPNT) dan bekerjasama menjadi mitra Bank BNI sebagai agen laku pandai.

Kegiatan usaha awal tersebut menjadi spirit bagi bumdes karena memiliki kegiatan usaha yang tersistem dan lebih dekat dengan masyarakat. Dalam perjalanan hampir satu tahun penyaluran BPNT mengalami perubahan teknis, dimana penyalur 
Research Fair Unisri 2019

Vol 4, Number 1, Januari 2020
P- ISSN: 2550-0171

E- ISSN: 2580-5819
BPNT kemudian bergeser ke e-warung masyarakat dan bumdes menjadi salahsatu suplair komoditi BPNT. Kegiatan usaha Bumdes yang lain misalnya membuka obyek wisata baru, pertokoan, perdagangan, aneka industri kerajinan, dan jenis usaha lainya serta telah mengadakan pameran baik di kecamatan maupun tingkat Kabupaten. Pada awal tahun 2019 setiap Bumdes juga telah membuat laporan keuangan sederhana untuk kegiatan usaha periode 2018 yang dikoordinir dan dispermaes dan P3A Kabupaten Kebumen. Sesuai AD/ART pendirian bumdes, maka hasil dari kegiatan usaha bumdes aai kan menjadi pemasukan atau kontribusi pendapatan asli desa (PADes) dan dibagikan kepada para pemilik modal serta insentif bagi pengurus.

Jenis usaha bumdes menurut Peraturan Menteri Desa, Pembangunan Daerah Tertinggal, Dan Transmigrasi No. 4 Tahun 2015 (Pasal 19) diantaranya yaitu; usaha social, persewaan, brokering, unit usaha lokal desa/kawasan perdesaan, usaha keuangan dan holding. Selain itu BUMdes juga bisa membuka usaha sub sektor pertanian, jasa konstruksi, perdagangan, dan handy craft. Luasnya peluang usaha BUMdes selain mencari laba (profit oriented) juga bersifat sosial (social entrepneur) sehingga selain target laba, diharapkan juga mampu menjadi penggerak ekonomi desa, membuka kesempatan kerja, menekan kemiskinan serta meningkatkan pemberdayaan dan kesejahteraan masyarakat. Kreatifitas usaha yang dilakukan BUMDes di Kebumen dalam mencapai tujuanya meliputi beberapa jenis usaha

\section{Identifikasi Faktor Internal dan Eksternal BUMDes}

Faktor-faktor kekuatan dan kelemahan BUMDes dapat diketahui dengan melakukan identifikasi faktor internal. Sedangkan untuk mengamati kondisi dan kecenderungan yang berada diluar kendali bumdes dilakukan dengan menganalisis faktor eksternal. Fokus dalam analisis faktor eksternal adalah untuk mengevaluasi dan mendapatkan faktor-faktor kunci yang menjadi peluang dan ancaman dalam proses pengembangan bumdes di kebumen. Dengan analisis dan identifikasi akan memudahkan penentuan alternatif strategi pengembangan Bumdes.

Tabel 3. Internal Faktor Evaluation (IFE)

\begin{tabular}{|c|c|c|}
\hline INTERNAL & KEKUATAN & KELEMAHAN \\
\hline $\begin{array}{l}\text { Sumber } \\
\text { Ekonomi } \\
\text { lokal }\end{array}$ & $\begin{array}{l}\text { a. Lahan sektor } \\
\text { pertanian luas } \\
\text { b. Potensi kekayaan } \\
\text { alam } \\
\text { c. Potensi sumber } \\
\text { daya manusia } \\
\end{array}$ & $\begin{array}{l}\text { a. Sektor pertanian belum } \\
\text { optimal } \\
\text { b. Pengembangan potensi } \\
\text { desa } \\
\text { c. Pemberdayaan lembaga } \\
\text { perekonomian }\end{array}$ \\
\hline Fasilitas & $\begin{array}{l}\text { a. Memiliki legalitas } \\
\text { hukum } \\
\text { b. Infrastruktur desa } \\
\text { c. Tersedia } \\
\text { teknologi tepat } \\
\text { guna }\end{array}$ & $\begin{array}{l}\text { a. Kelembagaan } \\
\text { penunjang } \\
\text { b. Sarana prasarana } \\
\text { penunjang } \\
\text { c. Pemanfaatan teknologi } \\
\text { kurang tepat guna } \\
\end{array}$ \\
\hline $\begin{array}{l}\text { Sektor } \\
\text { ekonomi } \\
\text { informal }\end{array}$ & $\begin{array}{l}\text { a. Industri lokal } \\
\text { b. Perdagangan dan } \\
\text { jasa umum } \\
\text { c. Kelompok usaha } \\
\text { masyarakat } \\
\end{array}$ & $\begin{array}{l}\text { a. Manajemen tradisional } \\
\text { b. Pemasaran tidak } \\
\quad \text { tersistem } \\
\text { c. Likuiditas rendah }\end{array}$ \\
\hline $\begin{array}{l}\text { Manajemen } \\
\text { dan lembaga }\end{array}$ & $\begin{array}{l}\text { a. Memiliki struktur } \\
\text { lembaga } \\
\text { b. Kewirausahaan } \\
\text { sosial } \\
\text { c. Memiliki jaringan } \\
\text { luas }\end{array}$ & $\begin{array}{l}\text { a. Penataan lembaga } \\
\text { belum efektif } \\
\text { b. Kreatifitas/ inovasi } \\
\text { rendah } \\
\text { c. Kegiatan usaha lambat }\end{array}$ \\
\hline $\begin{array}{l}\text { Sumber Daya } \\
\text { Manusia }\end{array}$ & $\begin{array}{l}\text { a. Pengurus bumdes } \\
\text { warga lokal } \\
\text { b. Kebersamaan } \\
\text { masyarakat } \\
\text { c. Ketersediaan } \\
\text { tenaga kerja }\end{array}$ & $\begin{array}{l}\text { a. Pengalaman wirausaha } \\
\text { lemah } \\
\text { b. Belum paham esensi } \\
\text { bumdes } \\
\text { c. Tenaga ahli }\end{array}$ \\
\hline Keuangan & $\begin{array}{l}\text { a. Memiliki modal } \\
\text { awal } \\
\text { b. Cash flow positif } \\
\text { c. Modal dari } \\
\text { pemerintah dan } \\
\text { masyarakat } \\
\end{array}$ & $\begin{array}{l}\text { a. Modal terbatas } \\
\text { b. Laba masih relatif kecil } \\
\text { c. Sistem administrasi } \\
\text { keuangan }\end{array}$ \\
\hline
\end{tabular}

Berdasarkan identifikasi faktor eksternal diketahui peluang dan ancaman bagi BUMDes. Kondisi lingkungan eksternal yang diamati adalah teknologi, mitra bisnis, pemerintah, potensi desa, partisipasi masyarakat dan pesaing.

Tabel 4. External Faktor Evaluation (EFE)

\begin{tabular}{|c|c|c|}
\hline $\begin{array}{l}\text { Faktor } \\
\text { External }\end{array}$ & PELUANG & ANCAMAN \\
\hline Teknologi & $\begin{array}{l}\text { a. Penerapan ilmu dan } \\
\text { teknologi } \\
\text { b. Pemasaran bisnis } \\
\text { basis on-line } \\
\text { c. Kemudahan } \\
\text { Informasi pasar }\end{array}$ & 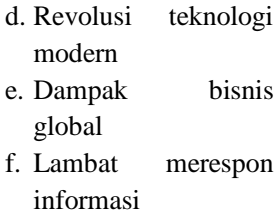 \\
\hline Mitra Bisnis & $\begin{array}{l}\text { a. Kerjasama usaha } \\
\text { lebih terbuka } \\
\text { b. Perluasan jaringan } \\
\text { usaha } \\
\text { c. Investasi yang } \\
\text { menguntungkan }\end{array}$ & $\begin{array}{l}\text { a. Usaha lain lebih } \\
\text { profesional } \\
\text { b. Mitra beralih ke yang } \\
\text { lain } \\
\text { c. Penarikan modal } \\
\text { investor }\end{array}$ \\
\hline
\end{tabular}


Research Fair Unisri 2019

Vol 4, Number 1, Januari 2020
P- ISSN: 2550-0171

E- ISSN: 2580-5819

\begin{tabular}{|c|c|c|}
\hline Pemerintah & $\begin{array}{l}\text { a. Dukungan } \\
\text { pemerintah } \\
\text { b. Menjadi rekanan } \\
\text { pemerintah }\end{array}$ & $\begin{array}{l}\text { a. Perubahan regulasi } \\
\text { b. Pergeseran struktur }\end{array}$ \\
\hline $\begin{array}{l}\text { Potensi } \\
\text { ekonomi } \\
\text { Desa }\end{array}$ & $\begin{array}{l}\text { a. Pengembangan } \\
\text { sumber daya } \\
\text { ekonomi lokal } \\
\text { b. Keberadaan pasar } \\
\text { potensial } \\
\text { c. Pengembangan } \\
\text { destinasi wisata }\end{array}$ & $\begin{array}{l}\text { a. Sistem kapitalisasi } \\
\text { b. Benturan } \\
\text { kepentingan } \\
\text { c. SDM kurang trampil }\end{array}$ \\
\hline $\begin{array}{l}\text { Persaingan } \\
\text { usaha }\end{array}$ & $\begin{array}{l}\text { a. Harga relatif febih } \\
\text { kompetitif } \\
\text { b. Menjalin kerjasama/ } \\
\text { konsinyasi } \\
\text { c. Inspirasi peniruan } \\
\text { kreatif }\end{array}$ & $\begin{array}{l}\text { a. Fluktuasi harga } \\
\text { produk } \\
\text { b. Pesaing lebih agresif } \\
\text { c. Komplain dari } \\
\text { pesaing }\end{array}$ \\
\hline Masyarakat & $\begin{array}{l}\text { a. Pemberdayaan } \\
\text { masyarakat } \\
\text { b. Kepercayaan } \\
\text { masyarakat } \\
\text { c. Budaya masyarakat }\end{array}$ & $\begin{array}{l}\text { a. Persepsi masyarakat } \\
\text { b. Perubahan minat } \\
\text { usaha } \\
\text { c. Kecemburuan sosial }\end{array}$ \\
\hline
\end{tabular}

\section{Alternatif Strategi Pengembangan BUMDes}

Dari hasil perhitungan matrix IFE dan EFE, didapatkan formulasi strategi yang tepat untuk diterapkan BUMDes adalah strategi pengembangan minat usaha masyrakat atau diversifikasi produk dan strategi penetrasi pasar. Hal ini didasari oleh hasil pemetaan total matriks IFE dan total matriks EFE pada matriks IE. Berdasarkan posisi tersebut dapat ditentukan bahwa posisi BUMDes saat ini berada pada sel V seperti pada tabel 5 berikut ini.

\section{Tabel 5. Matriks IE}

\begin{tabular}{|c|c|c|c|c|}
\hline \multirow{4}{*}{$\begin{array}{c}\text { Total } \\
\text { Rata-Rata } \\
\text { Tertimbang } \\
\text { EFE }\end{array}$} & & $\begin{array}{c}\text { Kuat } \\
3,0-4,0\end{array}$ & $\begin{array}{c}\text { Ratarata } \\
2,0-2,99\end{array}$ & $\begin{array}{l}\text { Lemah } \\
1,0-1,99\end{array}$ \\
\hline & Tinggi 3,0 - 4,0 & I & II & III \\
\hline & $\begin{array}{c}\text { Menengah 2,0 } \\
-2,99\end{array}$ & IV & V & VI \\
\hline & $\begin{array}{c}\text { Rendah } 1,0- \\
1,99\end{array}$ & VII & VIII & IX \\
\hline
\end{tabular}

Mengacu pada kedua jenis strategi tersebut, maka dilakukan pengembangan strategi menggunakan analisis SWOT dan diperoleh 16 alternatif strategi yang dapat digunakan dalam pengembangan BUMDes. Alternatif strategi tersebt dapat dilihat pada tabel berikut ini.

Tabel 6 Perumusan Alternatif Strategi

\begin{tabular}{|c|c|c|}
\hline EFE & $\begin{array}{c}\text { Strategi S-O } \\
\text { (kekuatan- } \\
\text { peluang) }\end{array}$ & $\begin{array}{l}\text { Strategi W-O: } \\
\text { (kelemahan- } \\
\text { peluang) }\end{array}$ \\
\hline
\end{tabular}

\begin{tabular}{|c|c|c|}
\hline $\begin{array}{l}\text { Peluang } \\
\text { Eksternal }\end{array}$ & $\begin{array}{ll}\text { 1. } & \text { Peningkatan } \\
\text { kinerja } \\
\text { BUMDes } \\
\text { 2. } & \text { Optimalisasi } \\
\text { potensi } \\
\text { ekonomi desa } \\
\text { dan } \\
\text { pemanfaatan } \\
\text { teknologi } \\
\text { 3. } \begin{array}{l}\text { Inovasi dan } \\
\text { pengembangan }\end{array} \\
\text { produk } \\
\text { 4. } \\
\text { Meningkatkan } \\
\text { produksi dan } \\
\text { penetrasi } \\
\text { pemasaran }\end{array}$ & 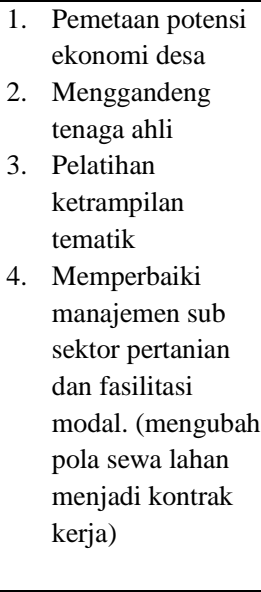 \\
\hline \multirow[t]{2}{*}{$\begin{array}{l}\text { Ancaman } \\
\text { Eksternal }\end{array}$} & $\begin{array}{c}\text { Strategi S-T } \\
\text { (kekuatan - } \\
\text { ancaman) }\end{array}$ & $\begin{array}{c}\text { Strategi W-T } \\
\text { (Kelemahan- } \\
\text { ancaman) }\end{array}$ \\
\hline & 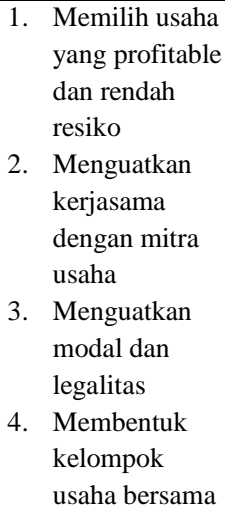 & $\begin{array}{ll}\text { 1. } & \text { Melakukan } \\
\text { evaluasi bisnis } \\
\text { 2. } & \text { Mengurangi } \\
\text { kegiatan usaha } \\
\text { yang kurang } \\
\text { produktif } \\
\text { 3. } & \text { Pelatihan dan } \\
\text { konsultasi } \\
\text { 4. }\end{array}$ \\
\hline
\end{tabular}

\section{Evaluasi Faktor Internal (IFE)}

Perumusaan strategi pengembangan Bumdes di Kebumen ini menggunakan Matrik SWOT. Penggunaan metode ini dapat menggambarkan bagaimana Bumdes memanfaatkan peluang dengan kekuatan dan kelemahan yang dimiliki serta dalam menghadapi ancaman eksternal. Matriks ini menghasilkan empat sel kemungkinan alternatif strategi, yaitu strategi S-O, W-O, W-T dan strategi S-T. Berikut tabel hasil perhitungan evaluasi faktor internal dan eksternal.

Tabel 7. IFE Matriks

\begin{tabular}{|c|c|c|c|c|}
\hline \multicolumn{2}{|r|}{ Faktor Internal } & Bobot & $\begin{array}{l}\text { Rat } \\
\text { ing }\end{array}$ & Nilai \\
\hline \multicolumn{5}{|c|}{ Kriteria Strength $(S)$} \\
\hline S1 & Lahan sektor pertanian luas & 0.027 & 3 & 0.081 \\
\hline S2 & Potensi kekayaan alam & 0.026 & 4 & 0.106 \\
\hline S3 & Potensi sumber daya manusia & 0.027 & 3 & 0.082 \\
\hline $\mathrm{S} 4$ & Memiliki legalitas hukum & 0.027 & 2 & 0.054 \\
\hline S5 & Infrastruktur desa & 0.028 & 3 & 0.085 \\
\hline S6 & Tersedia teknologi tepat guna & 0.031 & 3 & 0.093 \\
\hline S7 & Industri lokal & 0.029 & 3 & 0.088 \\
\hline S8 & Perdagangan\&jasa umum & 0.029 & 3 & 0.087 \\
\hline S9 & Kelompok usaha masyarakat & 0.029 & 4 & 0.115 \\
\hline
\end{tabular}


Research Fair Unisri 2019

Vol 4, Number 1, Januari 2020

\section{P- ISSN: 2550-0171 \\ E- ISSN: 2580-5819}

\begin{tabular}{|c|c|c|c|c|}
\hline \multicolumn{2}{|r|}{ Faktor Internal } & Bobot & Rat & Nilai \\
\hline S10 & Memiliki struktur lembaga & 0.027 & 3 & 0.081 \\
\hline S11 & Kewirausahaan sosial & 0.027 & 4 & 0.108 \\
\hline S12 & Memiliki jaringan luas & 0.029 & 2 & 0.058 \\
\hline S13 & Pengurus bumdes warga lokal & 0.027 & 3 & 0.082 \\
\hline S14 & Kebersamaan masyarakat & 0.028 & 3 & 0.084 \\
\hline S15 & Ketersediaan tenaga kerja & 0.028 & 3 & 0.084 \\
\hline S16 & Memiliki modal awal & 0.027 & 3 & 0.081 \\
\hline S17 & Cash flow positif & 0.027 & 2 & 0.053 \\
\hline S18 & $\begin{array}{l}\text { Modal dari pemerintah dan } \\
\text { masyarakat }\end{array}$ & 0.026 & 4 & 0.106 \\
\hline \multicolumn{5}{|c|}{ Kriteria Weakness $(W)$} \\
\hline W1 & Sektor pertanian belum optimal & 0.027 & 4 & 0.110 \\
\hline W2 & Pengembangan potensi desa & 0.027 & 3 & 0.081 \\
\hline W3 & $\begin{array}{l}\text { Pemberdayaan lembaga } \\
\text { perekonomian }\end{array}$ & 0.027 & 2 & 0.053 \\
\hline W4 & Kelembagaan penunjang & 0.029 & 2 & 0.058 \\
\hline W5 & Sarana prasarana penunjang & 0.028 & 3 & 0.083 \\
\hline W6 & $\begin{array}{l}\text { Pemanfaatan teknologi kurang } \\
\text { tepat guna }\end{array}$ & 0.028 & 3 & 0.083 \\
\hline W7 & Manajemen tradisional & 0.027 & 3 & 0.082 \\
\hline W8 & Pemasaran tidak tersistem & 0.026 & 3 & 0.079 \\
\hline W9 & Likuiditas rendah & 0.029 & 2 & 0.058 \\
\hline W10 & $\begin{array}{l}\text { Penataan lembaga belum } \\
\text { efektif }\end{array}$ & 0.027 & 2 & 0.053 \\
\hline W11 & Kreatifitas/ inovasi rendah & 0.028 & 3 & 0.084 \\
\hline W12 & kegiatan usaha lambat & 0.028 & 3 & 0.083 \\
\hline W13 & Pengalaman wirausaha lemah & 0.027 & 4 & 0.110 \\
\hline W14 & Belum paham esensi bumdes & 0.028 & 3 & 0.085 \\
\hline W15 & Tenaga ahli & 0.030 & 2 & 0.059 \\
\hline W16 & Modal terbatas & 0.028 & 4 & 0.111 \\
\hline W17 & Laba masih relatif kecil & 0.027 & 2 & 0.054 \\
\hline W18 & Sistem administrasi keuangan & 0.028 & 2 & 0.055 \\
\hline \multicolumn{2}{|r|}{ Total } & 1.000 & & 2.913 \\
\hline
\end{tabular}

Berdasarkan tabel 7 diketahui ada 6 kriteria dan 18 subkriteria yang menjadi faktor kunci kekuatan BUMDes dalam pengembangan Ekonomi Desa, meliputi Sumber Ekonomi lokal, Fasilitas, Sektor ekonomi informal, Manajemen dan lembaga, SDM dan Keuangan.

Dari ke-36 subkritria, nilai tertinggi adalah Kelompok usaha masyarakat dengan skor 0.115 dengan rating 4 yang merupakan kekuatan unggulan BUMDes. Hal ini menunjukkan bahwa Kelompok usaha masyarakat merupakan faktor yang sangat penting dalam pengembangan BUMDes. Setiap desa memiliki perbedaan karakteristik dan keunggulan potensi, tetapi secara umum pemanfaatanya belum optimal sehingga membutuhkan kreatifitas masyarakat untuk menggali, kerja keras, peran dunia usaha dan dukungan pemerintah. Dengan semangat gotongroyong dan rasa kekeluargaan yang kuat maka penerapan kewirausahaan sosial merupakan suatu pendekatan yang dapat dilakukan untuk meningkatkan kesejahteraan masyarakat. Masyarakat dapat melakukan rembug desa untuk menggali pemanfaatan kekayaan potensi ekonomi desa dan pemberian fasilitasi dari pemerintah baik dengan pemberian modal, peralatan, pelatihan maupun pendampingan usaha. Keberadaan Bumdes diharapkan mampu mengoptimalkan potensi ekonomi berbasis sumberdaya lokal untuk.meningkatkan ekonomi masyarakat dan pendapatan asli desa.

Dengan semangat kebersamaan mbangun desa, diharapkan faktor kelemahan yang ada dapat diminimalisir. Kelemahan yang cukup menonjol didesa diantaranya yaitu masyarakat belum memiliki skill yang memadai, keterbatasan modal, minimnya teknologi dan sistem perekonomian tradisional. Untuk itu maka pemerintah harus dapat mengambil kebijakan yang tepat, aktif melakukan pembagunan secara terus menerus, memberikan pembelajaran melalui berbagai bidang kegiatan yang dapat mendukung masyarakat dalam rangka meningkatkan perekonomian dan kesejahteraan. namun tugas pemerintahan sangat banyak sehingga menjadi kurang optimal dalam menjalankan tugasnya khususnya bidang perekonomian kepada masyarakat. Disinilah pentingnya peran bumdes dalam mengembangan perekonomian dan mengoptimalisasikan potensi ekonomi desa. Bumdes sebagai lembaga ekonomi yang pengelolaanya terpisah dari desa, sangat strategis untuk menjadi lokomotif dalam menggerakan perekonomian desa. dalam kurun waktu 3 tahun berjalan sejak 2017, seluruh desa di Kabupaten Kebumen telah mendirikan Bumdes. Dari 449 desa yang ada, terdapat 179 bumdes yang sudah mulai merintis usaha dengan berbagai jenis usaha.

Dari hasil wawancara langsun dengan para pengelola bumdes, salahsatu kelemahan utama adalah keterbatasan modal dan keahlian berwirausaha. Hal ini dapat dipahami karena bumdes baru berdiri dan masih dalam taraf pengembangan. Oleh karenanya, dibutuhkan adanya konsultan pendamping yang menguasai bidang usaha 


\section{Research Fair Unisri 2019 \\ Vol 4, Number 1, Januari 2020}

P- ISSN: 2550-0171

E- ISSN: 2580-5819 khususnya kewirausahaan sosial. Seiring dengan majunya bumdes maka akan semakin manarik minat investor untuk menanamkan modalnya baik dari pemerintah, masyarakat, perbankan maupun pihak eksternal.

\section{Hasil Evaluasi Lingkungan Eksternal}

Identifikasi yang dilakukan terhadap lingkungan eksternal BUMDes, menun-jukkan adanya beberapa faktor berpengaruh yang terdiri dari peluang dan ancaman. Faktor-faktor tersebut kemudian dievalusi menggunakan Matriks External Factor Evaluation (EFE). Dengan melakukan evaluasi terhadap faktor-faktor tersebut, dapat ditentukan strategi yang tepat dalam melakukan pengembangan BUMDes.

\section{Tabel 8 Matriks EFE}

\begin{tabular}{|c|c|c|c|c|}
\hline & Faktor Internal & Bo-bot & $\begin{array}{c}\text { Rati } \\
\text { ng }\end{array}$ & Nilai \\
\hline \multicolumn{5}{|c|}{ Kriteria Opportunity $(O)$} \\
\hline $\mathrm{O} 1$ & Penerapan ilmu dan teknologi & 0.030 & 3 & 0.089 \\
\hline $\mathrm{O} 2$ & Pemasaran bisnis basis on-line & 0.029 & 3 & 0.087 \\
\hline $\mathrm{O} 3$ & Kemudahan Informasi pasar & 0.029 & 3 & 0.086 \\
\hline $\mathrm{O} 4$ & Kerjasama usaha lebih terbuka & 0.030 & 2 & 0.059 \\
\hline O5 & Perluasan jaringan usaha & 0.030 & 3 & 0.089 \\
\hline O6 & Investasi yang menguntungkan & 0.031 & 4 & 0.124 \\
\hline O7 & Dukungan pemerintah & 0.031 & 4 & 0.124 \\
\hline O8 & Menjadi rekanan pemerintah & 0.030 & 3 & 0.091 \\
\hline O9 & $\begin{array}{l}\text { Pengembangan sumber daya } \\
\text { ekonomi lokal }\end{array}$ & 0.030 & 4 & 0.122 \\
\hline O10 & Keberadaan pasar potensial & 0.029 & 2 & 0.058 \\
\hline $\mathrm{O} 11$ & Pengembangan destinasi wisata & 0.030 & 3 & 0.089 \\
\hline $\mathrm{O} 12$ & Harga relatif febih kompetitif & 0.029 & 3 & 0.086 \\
\hline $\mathrm{O} 13$ & Menjalin kerjasama/ konsinyasi & 0.029 & 3 & 0.086 \\
\hline $\mathrm{O} 14$ & Inspirasi peniruan kreatif & 0.028 & 4 & 0.112 \\
\hline O15 & Pemberdayaan masyarakat & 0.028 & 3 & 0.085 \\
\hline O16 & Kepercayaan masyarakat & 0.028 & 2 & 0.056 \\
\hline $\mathrm{O} 17$ & Budaya masyarakat & 0.029 & 2 & 0.058 \\
\hline \multicolumn{5}{|c|}{ Kriteria Threat $(T)$} \\
\hline T1 & Revolusi teknologi modern & 0.028 & 2 & 0.056 \\
\hline $\mathrm{T} 2$ & Dampak bisnis global & 0.030 & 1 & 0.030 \\
\hline T3 & Lambat merespon informasi & 0.029 & 2 & 0.058 \\
\hline $\mathrm{T} 4$ & Usaha lain lebih profesional & 0.028 & 3 & 0.085 \\
\hline T5 & Mitra beralih ke yang lain & 0.030 & 3 & 0.089 \\
\hline T6 & Penarikan modal investor & 0.030 & 2 & 0.059 \\
\hline T7 & Perubahan regulasi & 0.030 & 3 & 0.089 \\
\hline T8 & Pergeseran struktur & 0.028 & 3 & 0.085 \\
\hline T9 & Sistem kapitalisasi & 0.029 & 3 & 0.086 \\
\hline $\mathrm{T} 10$ & Benturan kepentingan & 0.030 & 2 & 0.059 \\
\hline $\mathrm{T} 11$ & SDM kurang trampil & 0.029 & 3 & 0.086 \\
\hline $\mathrm{T} 12$ & Fluktuasi harga produk & 0.030 & 2 & 0.060 \\
\hline $\mathrm{T} 13$ & Pesaing lebih agresif & 0.031 & 2 & 0.062 \\
\hline $\mathrm{T} 14$ & Komplain dari pesaing & 0.031 & 1 & 0.031 \\
\hline
\end{tabular}

\begin{tabular}{|c|l|r|c|c|}
\hline \multicolumn{2}{|c|}{ Faktor Internal } & Bo-bot & $\begin{array}{c}\text { Rati } \\
\text { ng }\end{array}$ & Nilai \\
\hline T15 & Persepsi masyarakat & 0.031 & 3 & 0.093 \\
\hline T16 & Perubahan minat usaha & 0.028 & 2 & 0.057 \\
\hline T17 & Kecemburuan sosial & 0.029 & 1 & 0.029 \\
\hline \multicolumn{2}{|c|}{ Total } & 1.000 & & 2.618 \\
\hline
\end{tabular}

Berdasarkan tabel Matriks EFE diatas dapat diketahui bahwa terdapat enam kritria yang terdiri dari 17 sub kriteria. Enam kriteria factor strategis peluang tersebut, potensi pasar merupakan faktor eksternal yang memiliki nilai skor paling tinggi adalah investasi yang menguntungkan dan dukungan pemerintah sebesar 0.124 dengan rating 4 . Hal ini menunjukkan bahwa potensi pasar merupakan faktor yang sangat penting dalam optimalisasi potensi ekonomi dan pengembangan BUMDes. Pemanfaatan peluang Potensi pasar yang tersedia di Kabupaten Kebumen mendorong untuk melakukan pengembangan potensi ekonomi baik bidang subsektor pertanian, pariwisata maupun industri. Pemanfaatan peluang pasar yang optimal akan mendorong pengembangan BUMDES, menguatkan ekonomi dan meningkatkan daya saing.

Besarnya potensi pasar yang dimiliki oleh suatu maupun pariwisata merupakan peluang bagi pelaku industri untuk dapat melakukan pengelolaan yang baik terhadap industri yang dimiliki. Dengan demikian, maka upaya pengembangan pada berbagai kegiatan usaha bumdes akan semakin meningkatkan bidang usaha baik dari sisi kuantitas, kualitas, maupun pelayanan. Menurut hasil evaluasi faktor strategis ancaman juga terdapat beberapa faktor ancaman yang kiranya dapat menghambat pengembangan BUMDes. Faktor yang dianggaap dapat menjadi penghambat antara lain yatu; Persepsi masyarakat, Mitra beralih ke yang lain, Perubahan regulasi, SDM kurang trampil dan Sistem kapitalisasi, Berdasarkan keempat faktor tersebut, Pengurangan minat usaha lokal merupakan factor ancaman yang dirasa sangat berpengaruh pada pengembangan BUMDes. 
Research Fair Unisri 2019

Vol 4, Number 1, Januari 2020

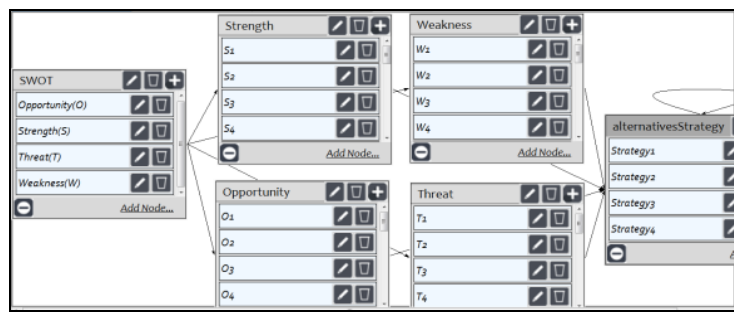

Gambar 4. Model Matriks ANP

Strategi dalam pengembangan BUMDes di Kebumen dirumuskan dengan menggunakan matrik SWOT. Hasil dari perumusan tersebut kemudian dipilih beberapa alternatif strategi yang terbaik. Setelah melakukan pemilihan, langkah selanjutnya yaitu menentukan prioritas strategi menggunakan pembobotan dengan metode Analytic Network Process (ANP). yaitu suatu metode yang memperhatikan keterkaitan antara strategi objeklif yang satu dengan yang lain.

Setelah ditentukan hubungan keterkaitan diantara tiap alternatif yang diperoleh, maka dilakukan pembobotan menggunakan metode ANP untuk menentukan nilai prioritas dari setiap alternatif strategi. Setiap alternatif strategi memiliki bobot prioritas yang berbeda-beda. Dasar pemilihan strategi pengembangan BUMDes yaitu berdasarkan nilai bobot yang telah disesuaikan. Dari hasil analisis matriks SWOT telah diperoleh beberapa alternatif strategi yang bisa diterapkan untuk pengembangan BUMDes di Kabupaten Kebumen. Berdasarkan hasil pembobotan yang ada pada Tabel 4.4, dapat diketahui urutan alternatif strategi mulai dari bobot yang tertinggi hingga terendah.

Tabel 9 Hasil Pemeringkatan Alternatif strategy

\begin{tabular}{|l|l|l|}
\hline Alternatif strategi & Normalized & Idealized \\
\hline $\begin{array}{l}\text { Fasilitasi modal dan memperbaiki kinerja } \\
\text { sektor pertanian }\end{array}$ & 0,155 & 1,000 \\
\hline Pemetaan potensi ekonomi desa & 0,128 & 0,825 \\
\hline Inovasi dan pengembangan produk 3 & 0,115 & 0,746 \\
\hline Meningaktkan produksi dan penetrasi pasar & 0,103 & 0,667 \\
\hline $\begin{array}{l}\text { Memilih usaha yang profitable dan rendah } \\
\text { resiko }\end{array}$ & 0,078 & 0,506 \\
\hline Peningkatan kinerja BUMDes & 0,071 & 0,460 \\
\hline $\begin{array}{l}\text { Optimalisasi potensi ekonomi desa dan } \\
\text { pemanfaatan teknologi }\end{array}$ & 0,065 & 0,422 \\
\hline Menguatkan modal dan legalitas & 0,060 & 0,386 \\
\hline Menguatkan kerjasama dengan mitra usaha & 0,048 & 0,309 \\
\hline $\begin{array}{l}\text { Pengadaan pusat informasi dan } \\
\text { pelayananan }\end{array}$ & 0,039 & 0,253 \\
\hline Membentuk kelompok usaha bersama & 0,035 & 0,227 \\
\hline
\end{tabular}

P- ISSN: 2550-0171

E- ISSN: 2580-5819

\begin{tabular}{|l|l|l|}
\hline Alternatif strategi & Normalized & Idealized \\
\hline Pelatihan ketrampilan tematik & 0,027 & 0,178 \\
\hline Menggandeng tenaga ahli & 0,022 & 0,143 \\
\hline Pelatihan dan konsultasi & 0,021 & 0,138 \\
\hline Melakukan evaluasi bisnis & 0,019 & 0,120 \\
\hline $\begin{array}{l}\text { Mengurangi kegiatan usaha yang kurang } \\
\text { produktif }\end{array}$ & 0,014 & 0,088 \\
\hline
\end{tabular}

\section{SIMPULAN DAN REKOMENDASI Simpulan}

Sesuai hasil evaluasi pada faktor internal teridentifikasi 2 kriteria yang terdiri dari 36 subkriteria dan pada faktor eksternal juga terdapat 2 kriteria dengan 34 subkriteria. Kriteria Faktor internal (kekuatan dan kelemahan) meliputi; Sumber ekonomi lokal, fasilitas, Sektor ekonomi informal, Manajemen dan kelembagaan, Sumber Daya Manusia, dan Keuangan. Kriteria pada faktor eksternal (peluang dan ancaman) meliputi; Teknologi, Mitra Bisnis, Pemerintah, Potensi ekonomi Desa, Persaingan usaha, dan Masyarakat.

Dari hasil pembobotan dan penentuan rating dengan metode SWOT, posisi Bumdes di Kebumen berada diposisi Sel V. Hal ini artinya strategi pengembangan BUMDes dapat dilakukan dengan cara mempertahankan dan memelihara (hold and maintenance). Dengan demikian, maka secara konsep strategi yang cocok untuk digunakan adalah diversifikasi produk dan penetrasi pasar. Berdasarkan konsep strategi tersebut kemudian dirumuskan kedalam 16 alternatif strategi dalam rangka pengembangan bumdes.

Penentuan prioritas ke-16 Alternatif strategi pengembangan bumdes menggunakan metode Analitical Network Proces (ANP) menghasilkan urutan perengkingan sebagai berikut:

Tabel 10 Urutan Prioritas Alternatif Strategy

\begin{tabular}{|c|l|}
\hline \multicolumn{2}{|l|}{ Urutan Peringkat Proritas Alternatif strategi } \\
\hline 1 & Fasilitasi modal dan memperbaiki kinerja sektor pertanian \\
\hline 2 & Pemetaan potensi ekonomi desa \\
\hline 3 & Inovasi dan pengembangan produk \\
\hline 4 & Meningaktkan produksi dan penetrasi pasar \\
\hline
\end{tabular}


Research Fair Unisri 2019

Vol 4, Number 1, Januari 2020
P- ISSN: 2550-0171

E- ISSN: 2580-5819

\begin{tabular}{|r|l|}
\hline 5 & Memilih usaha profitable dan rendah resiko \\
\hline 6 & Peningkatan kinerja BUMDes \\
\hline 7 & $\begin{array}{l}\text { Optimalisasi potensi ekonomi desa dan pemanfaatan } \\
\text { teknologi }\end{array}$ \\
\hline 8 & Menguatkan modal dan legalitas \\
\hline 9 & Menguatkan kerjasama dengan mitra usaha \\
\hline 10 & Pengadaan pusat informasi dan pelayananan \\
\hline 11 & Membentuk kelompok usaha bersama \\
\hline 12 & Pelatihan ketrampilan tematik \\
\hline 13 & Menggandeng tenaga ahli \\
\hline 14 & Pelatihan dan konsultasi \\
\hline 15 & Melakukan evaluasi bisnis \\
\hline 16 & Mengurangi usaha yang kurang produktif \\
\hline
\end{tabular}

\section{Rekomendasi}

Mendasarkan pada hasil analisa SWOT dan pemilihan alteratif strategi pengembangan BUMDes untuk meningkatkan perekonomian masyarakat dan Pendapatan Asi Desa (PADes) dapat direkomendasikan beberapa hal:

1. Pentingnya pemerintah mensupport kinerja BUMDes melalui kebijakan regulasi, fasilitasi permodalan dan pendampingan.

2. Melakukan perencanaan strategi pengembangan bumdes yang baik, pengamatan mendalam dan pemetaan potensi ekonomi desa, memilih usaha profitable, mengikis praktik kapitalis dan meluaskan jaringan mitra bisnis.

3. Mengoptimalkan peran mitra ekonomi, investor dan masyarakat untuk bersama-sama dalam mendorong peningkatan produk, diversifikasi produk dan menguatkan pasar.

\section{DAFTAR PUSTAKA}

Anggraeni, Maria Rosa Ratna Sri, 2016. Peranan Badan Usaha Milik Desa (Bumdes) Pada Kesejahteraan Masyarakat Pedesaan. Studi Pada Bumdes Di Gunung Kidul, Yogyakarta. MODUS Vol.28 (2): 155-167, 2016

Assauri, S. 2004. Manajemen Pemasaran (Dasar,Konsep dan Strategi). PT. Grafindo Persada. Jakarta.

Bittel, E. 1994. Organisasi; Teori dan Praktek. Alih Bahasa: Andi. Jakarta: Gramedia.
Bryson, J, M. 2003. Perencanaan Strategi Bagi Organisasi Sosial. Alih Bahasa: M. Amin. Yogyakarta: Pustaka Pelajar.

Kossowski, A. 2007. Strategic Management: Porter's Model of Generic Co. GRIN Verlag

Lipinski, C. A. 2002. Poor Aqueous Solubility-an Industry Wide Problem in ADME Screening. American Pharmaceutical Review, 5, 82-85.

Certo. 1995. Strategic Management. Jakarta: Gunung Agung.

Creswell, John W. 2013 Researc Design pendekatan Kualitatif, Kuantitatif, dan Mixed. Pustaka Pelajar

Dyson, R. G. 2004. Strategic development and SWOT analysis at the University of Warwick. European journal of operational research, 152(3), 631-640.

http://dpr.go.id/berita/detail/id/15981/t/Desa+Sebaga i+Subjek+Pembangunan

Harmiati., Zulhakim, Abdul Aziz, Eksistensi Badan Usaha Milik Desa (Bumdes) Dalam Mengembangkan Usaha Dan Ekonomi Masyarakat Desa Yang Berdaya Saing Di Era Masyarakat Ekonomi Asean

honny Ibrahim, 2006, Teori dan Metodologi Penelitian Hukum Normatif, Malang: Banyumedia Publishing, hlm. 242

https://ekonomi.kompas.com/read/2015/12/07/16212 9826/Segera.Optimalkan.Potensi.Ekonomi.De sa.

http://www.berdesa.com/lawan-kemiskinan-desakewirausahaan-sosial/

https://kebumenkab.bps.go.id/dynamictable/2017/02 /17/128/jumlah-penduduk kabupatenkebumen-2016.html

Kebumen Dalam Angka https://www.kebumenkab.go.id/index.php/pub lic/page/index/51

Nofiratullah, 2018. Eksistensi Badan Usaha Milik Desa (Bumdes) Dalam Meningkatkan 
Research Fair Unisri 2019

Vol 4, Number 1, Januari 2020

Perekonomian Masyarakat Desa Soki Kecamatan Belo Kabupaten Bima

http://etheses.uinmalang.ac.id/11809/1/14130051.pd f 6/10/2018. 22.29wib

Peraturan Menteri Desa, Pembangunan Daerah Tertinggal dan Transmigrasi Republik Indonesia Nomor 4 Tahun 2015 tentang Pendirian, Pengurusan dan Pengelolaan BUMDes

Peraturan Pemerintah Nomor 72 Tahun 2005 tentang Desa

Program Desa Lestari. 2016. Pendekatan Utuh Penguatan Kelembagaan Ekonomi Desa. Yogyakarta: Yayasan Penabulu. Diakses melalui

http://m.kbr.id/muhamad_ridlo_susanto/01201 6/hadapi_mea_pemerintah_disarankan_berday akan_bumdes_/78047.html, tanggal 7/10/2018. 1/30wib.

Rangkuti F. 2003. Analisis SWOT Teknik Membedah Kasus Bisnis. PT. Gramedia Pustaka Utama. Jakarta.

2006. Analisis SWOT Teknik Membedah Kasus Bisnis: Reorientasi Konsep Perencanaan Strategi untuk Menghadapi Abad 21. Gramedia Pustaka Utama. Jakarta

2001). Manajemen Strategis. Alih Bahasa : Julianto Agung. Yogyakarta: Andi.

Soesilo, I Nining. 2002. Manajemen Stratejik di Sektor Publik (Pendekatan Praktis)Buku II. Jakarta: Universitas Indonesia.

Sugiyono. 2011. Metode Penelitian Kuantitatif, Kualitatif dan R\&D. Bandung: Afabeta

Sutoro, Eko bersama Tim FPPD. 2013. Policy Paper.Membangun Bumdes yang Mandiri, Kokoh dan Berkelanjutan.

Suwarjono, Muhammad 2000. Manajemen Strategik Konsep dan Kasus, YKPN. Yogyakarta.

Undang - Undang Nomer 6 Tahun 2014 tentang Desa.

\section{P- ISSN: 2550-0171 \\ E- ISSN: 2580-5819}

Undang- Undang Nomor 32 Tahun 2004 tentang pemerintah Daerah

Yudiardi, Dodi (2015) Strategi Pengembangan Badan Usaha Milik Desa (BUMDes) dalam meningkatkan prekonomian masyarakat perdesaan kabupaten Garut.

In: 9th International Conference on MalaysiaIndonesia Relations (PAHMI 9) Faculty Of Social Sciences Yogyakarta State University. Diunduh Melalui http://eprints.uny.ac.id/28003/ tanggal 7/10/2018. 2.03 wib. 